\title{
Ketogenic diet: a promising alternative nonpharmacology treatment for pediatric epilepsy
}

\author{
Bella Kurnia* \\ Faculty of Medicine, Kristen Krida Wacana University, Jakarta, Indonesia \\ Received: 08 April 2019 \\ Accepted: 02 May 2019 \\ *Correspondence: \\ Dr. Bella Kurnia, \\ E-mail: bellakurnia12@gmail.com \\ Copyright: ( ) the author(s), publisher and licensee Medip Academy. This is an open-access article distributed under \\ the terms of the Creative Commons Attribution Non-Commercial License, which permits unrestricted non-commercial \\ use, distribution, and reproduction in any medium, provided the original work is properly cited.
}

\begin{abstract}
Epilepsy is a syndrome of brain dysfunction induced by the aberrant excitability of certain neurons. Despite advances in surgical technique and anti-epileptic drug in recent years, recurrent epileptic seizures remain intractable and lead to a serious morbidity in the world. The ketogenic diet (KD) is a nonpharmacologic treatment that has been used for refractory epilepsy since 1921. The KD is a high-fat, low-carbohydrate, and restricted protein diet, which is calculated and weighed for each individual patient. The goal of the KD treatment is to bring the brain into a state of ketosis to control seizures. Many studies have shown that ketogenic diet was very useful in controlling refractory epilepsy.
\end{abstract}

Keywords: Ketogenic diet, Nonpharmacology, Pediatric epilepsy, Pediatric, Seizure

\section{INTRODUCTION}

Epilepsy is the most common serious neurological condition in the world, with an estimated prevalence of $1 \%$ of the population. The highest incidence occurs in childhood and in the elderly, and with lower levels in early adulthood. ${ }^{1}$ According to WHO in 2017, there were approximately 2.4 billion people diagnose with epilepsy ever year around the world. The lifetime risk of developing epilepsy is $3.9 \%$, with males have slightly higher risk than women. ${ }^{2}$

\section{REVIEW OF LITERATURE}

Traditional epilepsy management includes pharmacological treatment and surgery. Despite these therapies, $25 \%$ of children continue to have uncontrolled seizures. Deliberate fasting has been shown to control seizures. The impracticality of prolonged starvation became the drive to formulate the ketogenic diet. KD is a treatment option for many of these children. A meta- analysis of 19 studies with a combined sample of 1084 pediatric patients was complete in 1998 by Blue Cross Blue Sheld. Estimates of the overall efficacy of the KD in controlling seizures were reported as follows $16 \%$ became seizure free, $32 \%$ had a $>90 \%$ reduction in seizures and $56 \%$ had a $>50 \%$ reduction. $\mathrm{KD}$ is high in fat, moderate in protein, and low in carbohydrates. ${ }^{1}$ Now days the ketogenic diet was rarely used as the adjuvant therapy for epilepsy in children despite numerous evidence the efficacy of it.

\section{DEFINITION}

Seizure is defined as an excessive burst of abnormal synchronized neuron activity affecting small or large neuronal networks that results in clinical manifestations that are sudden, transient and usually brief.

Epilepsy is a disorder of the brain characterized by any of the following conditions: 
- $\quad$ At least two unprovoked seizures occurring >24 hour apart

- $\quad$ One unprovoked seizure and a probability of further seizures similar to the general recurrence risk after two unprovoked seizures, occurring over the next 10 years

- Diagnosis of an epilepsy. ${ }^{3}$

\section{ETIOLOGY}

A seizure may be an isolated event with no obvious cause or triggered by acute metabolic disturbances or fever. Epilepsy may be idiopathic (usually genetic), cryptogenic (undiagnosed cause with associated neurological or developmental deficits), or symptomatic (known cause).

\section{CLASSIFICATION}

Seizures can be clinical or subclinical (electrographic) with EEG but no clinical manifestations. The International league against Epilepsy (ILAE) classification system is summarized in Figure $1 .^{4}$

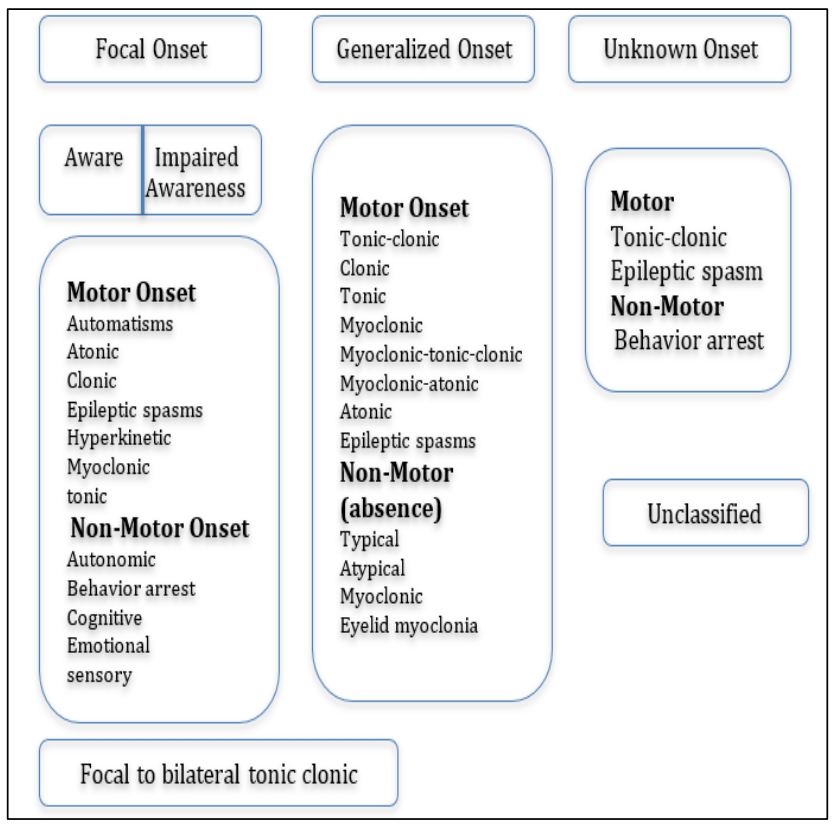

Figure 1: ILAE 2017 classification of seizure types. ${ }^{4}$

\section{MODE OF SEIZURE ONSET}

Generalized epileptic seizure are those that originating at some point within and rapidly engaging, bilaterally distributed networks, which can be subcortical or cortical structures, but do not essentially, include the entire cortex.

The term focal can be replaced with partial epileptic seizures, which are origination within one hemisphere. They may be localized or widely distributed. Focal seizures may originate in subcortical structures. ${ }^{3}$

\section{TYPES OF SEIZURES}

The type of seizures is summarized on Table 1.

\section{PATHOPHYSIOLOGY}

One commonality across epilepsies is a disrupted imbalance between excitatory (via glutamatergic signaling) and inhibitory (via GABAergic signaling) drive at the synaptic level that can result in seizure activity. ${ }^{5}$ A seizure results when a sudden imbalance occurs between the excitatory and inhibitory forces within the network of cortical neurons. The basic physiology of a seizure episode is detected to in an unstable cell membrane or its surrounding supportive cells. The seizure originates from the grey matter of any cortical or subcortical area. Initially a small number of neurons fire abnormally. Normal membrane conductance and inhibitory synaptic current breakdown and excess excitability spread either locally to produce a focal seizure or more widely to produce a generalized seizure. This onset propagates by physiologic pathways to involve adjacent to remote areas. As abnormality of potassium conductance, a defect in the voltage activated ion channels, or a deficiency in the membrane ATPase linked to ion transport may cause neuronal membrane unstable and cause a seizure. Certain neurotransmitters (e.g. glutamate, aspartate, acetyl choline, norepinephrine, histamine, corticotrophin releasing factor, purines, peptides, cytokines and steroid hormones) enhance the excitability and propagation of neuronal activity, whereas a-amino butyric acid (GABA) and dopamine inhibit neuronal activity and propagation. ${ }^{6}$

\section{DIAGNOSIS}

Diagnosis in epilepsy include establishing a seizure diagnosis and an etiologic diagnosis and identification of precipitating factors. This is accomplished by combination of history taking, physical examination, electroencephalographhy (EEG) and laboratory examinations. ${ }^{7}$ Diagnosis algorithm can be seen in Figure 2.

\section{MANAGEMENT Of EPILEPSY}

\section{Pharmacology}

Long term AED treatment should be started after the second seizure. The aim of the treatment is complete seizure control without significant adverse effects. All drugs are started in low dose and increased gradually up to a maximum dose till seizure control is achieved or side effects appear. If no control is obtained with maximum dose of first drug, then a second first line drug is initiated, and the first drug tapered. If partial contol is achieved, then a second AED should be added. Four major first line conventional anticonvulsants were phenobarbitone, phenytoin, valproate, and carbamazepine. Carbamazepine and valproate appear to be better tolarated than 
phenobarbitone and phenytoin. AED is withdrawn after 2 year of seizure freedom. All the drug dosage and usage can be seen in Table $2 .^{7}$ And the algorithm of status epilepticus management can be seen in Figure 3.

\section{REFRACTORY EPILEPSY}

Refractory epilepsy can be defined as epilepsy which is uncontrolled despite adequate trials of three first line AEDs and when it disrupts developmental progress or normal childhood activity. When faced with a child with uncontrolled epilepsy, always try and confirm whether the diagnosis is correct. Often non-epileptic conditions may be confused as seizures. The type of seizure and a correct diagnosis of the specific epilepsy syndrome may facilitate correct DOC. It is best to refer refractory epilepsy early to a tertiary center for appropriate evaluation (including highend MRI, video EEG etc.) and to get guidance on management options like newer AEDs, ketogenic diet and surgery. ${ }^{7}$

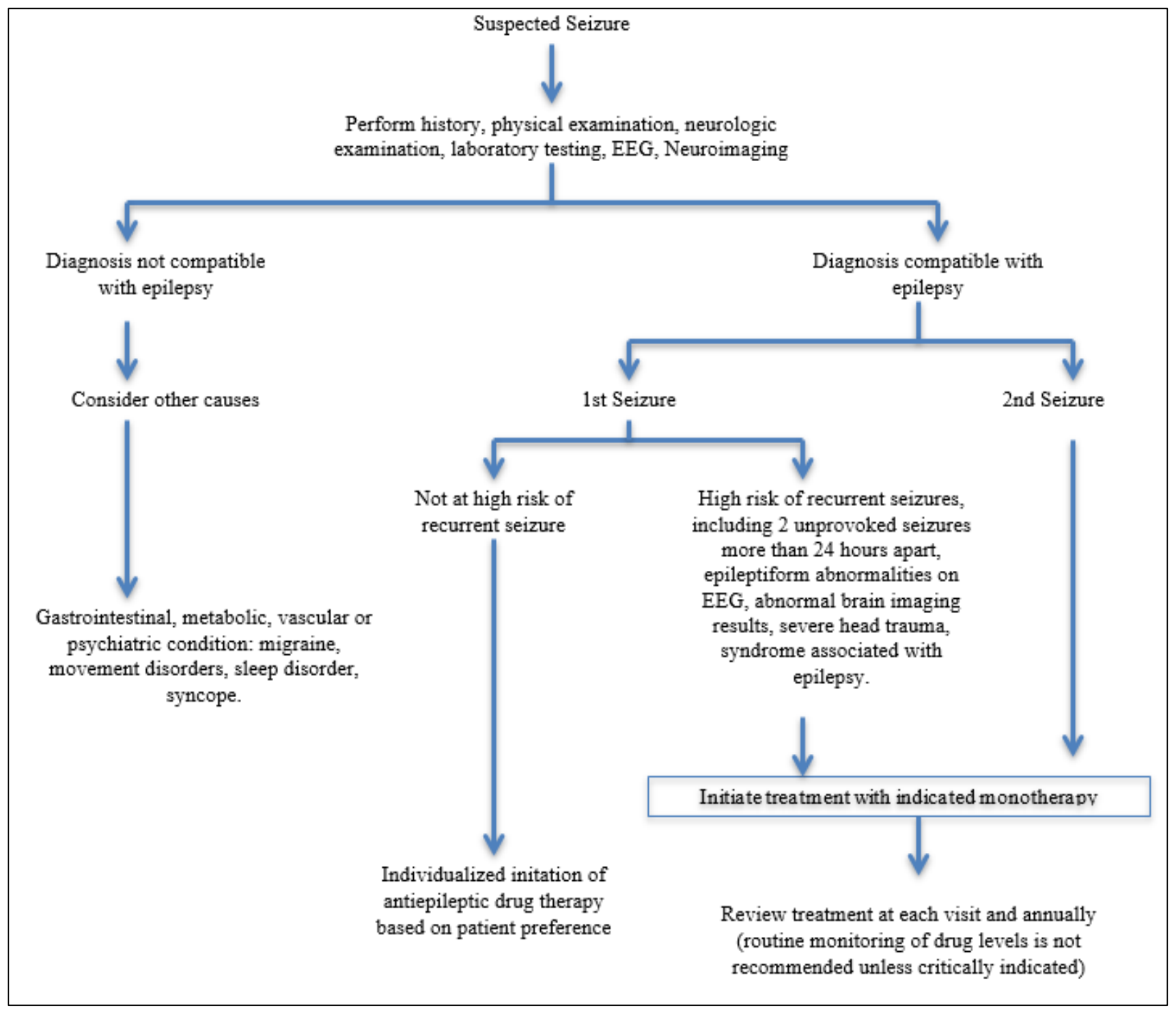

Figure 2: Diagnostic algorithm for epilepsi. ${ }^{2}$

\section{SURGERY INTERVENTIONS}

Up to $30 \%$ of patients with epilepsy can have medically refractory epilepsy. Surgical resection of the seizure focus in appropriately selected patients often results in decreased frequency or elimination of seizures with improvement in quality of life. Seizure freedom is achieved in up to $76 \%$ of patients after resection. ${ }^{2}$ Patients with intractable epilepsy resulting from metabolic or degenerative problems are not candidates for respective epilepsy surgery. Focal resection of the epileptogenic zone is the most common procedure. ${ }^{3}$ 
Table 1: Types of seizures..$^{3,4}$

\begin{tabular}{|c|c|c|c|}
\hline Types of seizure & Characteristics & Consciousness & EEG \\
\hline $\begin{array}{l}\text { Absence seizure } \\
\text { (Petit mal) }\end{array}$ & $\begin{array}{l}\text { - Generelized seizures } \\
\text { - A sudden onset behavioral arrest, blank } \\
\text { stare, unresponsiveness and sometimes } \\
\text { a brief upward rotation of the eyes. } \\
\text { - } \quad \text { Duration: few seconds to } 1 / 2 \mathrm{~min}\end{array}$ & $\begin{array}{l}\text { Little tonopostictal } \\
\text { confusion, the patient } \\
\text { resumes the activity } \\
\text { he/she was doing } \\
\text { prior to the seizures }\end{array}$ & $\begin{array}{l}\text { Pathognomonic: bilaterally } \\
\text { synchronous and symmetric } \\
\text { paroxysms of spike-and-wave } \\
\text { complexes at a frequency of } 3 \\
\text { hz appear during seizure }\end{array}$ \\
\hline $\begin{array}{l}\text { Myoclonic } \\
\text { seizure }\end{array}$ & $\begin{array}{l}\text { A sudden, brief, irregular and shock } \\
\text { like contractions that may be } \\
\text { generalized or confined to the face and } \\
\text { trunk, or to one or mor extremities, or } \\
\text { even to individual muscles. Can evolve } \\
\text { into tonic clonic } \\
\text { A single or repetitive twitch to a sever } \\
\text { jerking, symmetric/ asymmetric }\end{array}$ & $\begin{array}{ll}\text { - } & \text { No postictal } \\
\text { confusion } \\
\text { - No impaired } \\
\text { consciousness }\end{array}$ & $\begin{array}{l}\text { Brief generalized polyspikes } \\
\text { or polyspikes and wave } \\
\text { discharges with the myclonic } \\
\text { jerk }\end{array}$ \\
\hline Clonic seizures & $\begin{array}{l}\text { - } \text { Repetitive rhythmic clonic jerks } \\
\text { - A short postictal phase } \\
\text { - Can lead to tonic clonic seizure }\end{array}$ & $\begin{array}{l}\text { Impairment of } \\
\text { consciousness }\end{array}$ & $\begin{array}{l}\text { Generalized polyspikes and } \\
\text { wave discharges or } \\
\text { generelized fast activity }\end{array}$ \\
\hline Tonic seizures & $\begin{array}{l}\text { Brief seizures consisting of sudden } \\
\text { onset of increased tone in extensor } \\
\text { muscles }\end{array}$ & $\begin{array}{l}\text { Altered } \\
\text { consciousness }\end{array}$ & $\begin{array}{l}\text { Slowing of the background } \\
\text { with multifocal spikes, sharp } \\
\text { waves and bursts of irregular } \\
\text { spike and wave activity }\end{array}$ \\
\hline $\begin{array}{l}\text { Tonic clonic } \\
\text { (Grand Mal) }\end{array}$ & $\begin{array}{l}\text { Tonic extension and then clonic } \\
\text { convulsive movements of all } \\
\text { extremities. } \\
\text { May associated with aura (suggesting a } \\
\text { focal origin of epileptic discharge) }\end{array}$ & $\begin{array}{l}\text { Altered } \\
\text { consciousness }\end{array}$ & $\begin{array}{l}\text { - Generalized repetitive } \\
\text { spikes in the tonic phase } \\
\text { and then periodic spikes in } \\
\text { the clonic phase. } \\
\text { In between attacks, may } \\
\text { discharged brief generalized } \\
\text { spikes or spike wave that } \\
\text { are polymorphic }\end{array}$ \\
\hline $\begin{array}{l}\text { Epilepsy } \\
\text { syndromes }\end{array}$ & $\begin{array}{l}\text { A unique epilepsy condition with different } \\
\text { etiologies that involve more than just a } \\
\text { seizure type }\end{array}$ & & \\
\hline $\begin{array}{l}\text { Status } \\
\text { epilepticus }\end{array}$ & $\begin{array}{l}\text { A seizure or series of seizures, which } \\
\text { continue for at least } 30 \text { minutes }\end{array}$ & \multicolumn{2}{|c|}{ Without return of consciousness between the seizures } \\
\hline
\end{tabular}

\section{KETOGENIC DIET}

Nonpharmacologic approaches may be useful adjuncts in patients with difficult-to-control seizures or who find medication difficult to tolerate. One of the nonpharmacology therapy for those patients are ketogenic diet (KD). KD is a stringently controlled high fat and low protein/carbohydrate diet given with/without a restricted fluid intake to maintain ketosis on a long-term basis. It has been shown that it is more efficacious than newer AEDs in controlling refractory seizures and is more cost effective. ${ }^{7}$ The diet was designed to stimulate the ketosis of starvation by supplying fat as the main source of calories, while restricting protein and carbohydrate consumption. The exact mechanisms of seizure inhibition remain unknown, but its neuroprotective effects were demonstrated in the animal research, which no other antiepileptic therapy has provide. ${ }^{1}$ The "classic" $\mathrm{KD}$ is based upon consumption of long-chain saturated triglycerides in a $3: 1-4: 1$ ketogenic diet ratio of fats to carbohydrates+protein (by weight). The vast majority of calories $(>90 \%)$ are derived from fat. Diet treatment generally begins with a period of fasting followed by gradual increase in calories to a target $\mathrm{KD}$ ratio of $3: 1$ $4: 1$. This is conducted in the inpatient setting over the course of several days, where blood glucose, urine ketones, and several other metabolic variables are closely monitored. The hallmark feature of KD treatment is the production of ketone bodies by the liver. Ketone bodies provide an alternative substrate to glucose for energy utilization, and in developing brain, also constitute essential building blocks for biosynthesis of cell membranes and lipids. ${ }^{8}$ Initiation of KD most often occurs in an inpatient setting at an epilepsy center in order monitor the patients. Traditionally, the diet is initiated after a $24-48$ hour fasting period, and it is slowly introduced until the patient successfully achieves the full ketogenic diet to be discharged home with. The average 
hospital stay is four days, during which the family and the patient are educated on the diet. If ketosis is not maintained, the patient must return to the hospital to restart the entire diet initiation process, therefore, compliance with the diet is essential. ${ }^{9}$

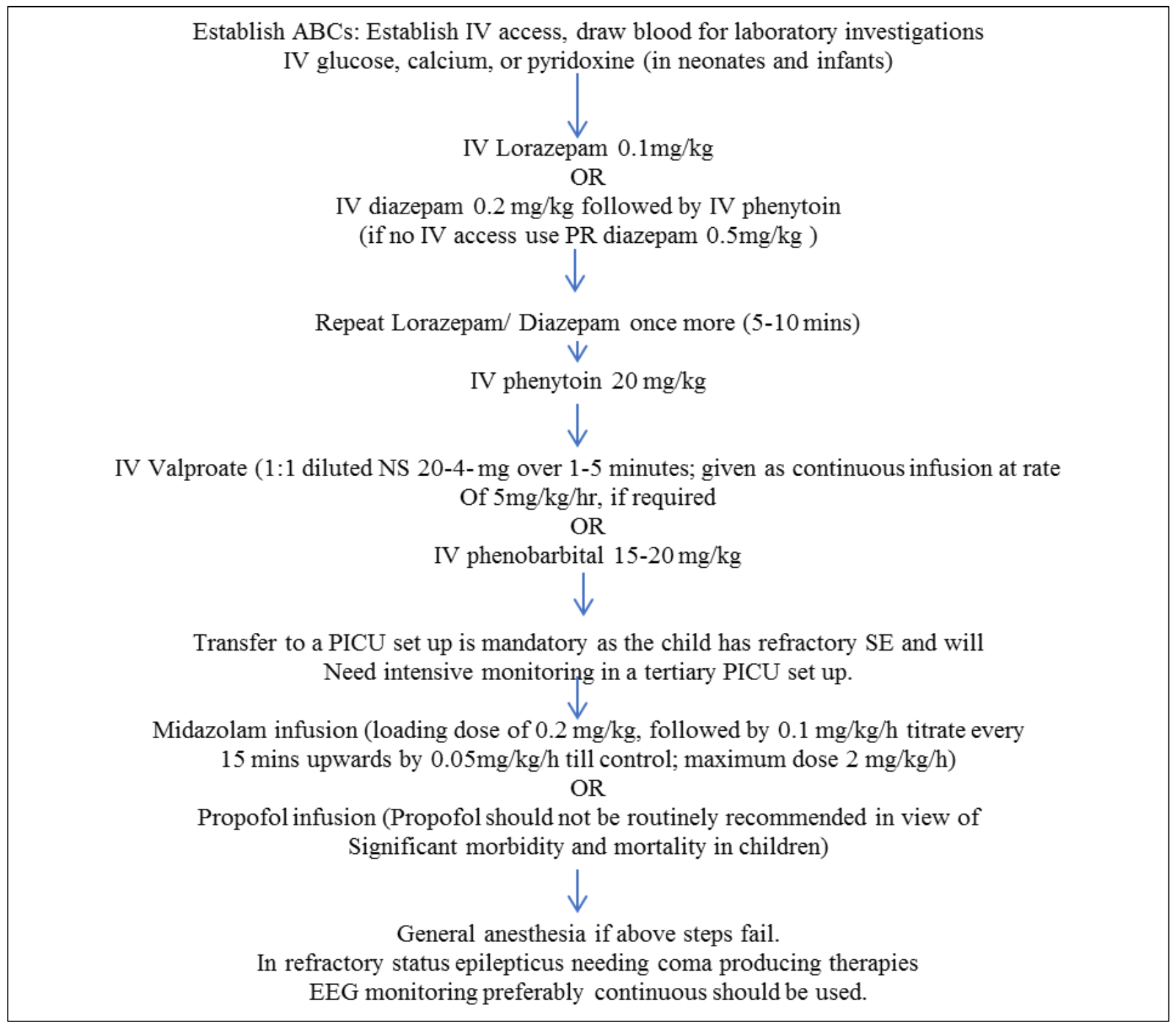

Figure 3: Management algorithm for status epilepticus. ${ }^{7}$

\section{From other studies}

A randomized controlled trial that tested the efficacy of the KD in children with intractable epilepsy found that $60 \%$ of patients had more than $50 \%$ seizure frequency reduction and $10 \%$ were seizure-free. Our sample population included patients $(50 \%)$ with Lennox Gastaut syndrome, who are more likely to experience a reduction in seizure frequency when receiving KD treatment. From Sampaio et al study, it can be seen that after three months, the responder rate (more than 50\% seizure frequency reduction) was $6 / 10(60 \%)$ and $10 \%$ of patients were seizure-free. ${ }^{10}$ According to Neal et al, their RCT on 145 children with refractory seizures shows that after 3 months, the mean percentage of baseline seizures was significantly lower in the diet group than in the controls (62.0\% vs $136.9 \%, 75 \%$ decrease, $95 \%$ CI $42.4-107.4 \%$, $\mathrm{p}<0.0001) .28$ children $(38 \%)$ in the diet group had $>50 \%$ seizure reduction compared with four $(6 \%)$ controls ( $\mathrm{p}<0.0001$ ), and five children $(7 \%)$ in the diet group had greater than $90 \%$ seizure reduction compared with no controls $(\mathrm{p}=0.0582) .{ }^{11}$ And according to Lamberechts et al, their RCT shows that KD is an effective therapy in children and adolescents with refractory epilepsy compared with care as usual. ${ }^{12,13}$ 


\section{Types of ketogenic diet}

Multiple variations of ketogenic diets exist, but the most commonly prescribed are the classic $\mathrm{KD}$, the modified
Atkins diet, the low-glycemic index treatment diet, the medium-chain triglyceride (MCT) diet, and the modified MCT diet. They were summarized in Table 3 and Table $4{ }^{9}$

Table 2: Anti-epileptic drug. ${ }^{7}$

\begin{tabular}{|c|c|c|c|}
\hline Name & Usage & Dosage (Mg/Kg/Day) & Side effect \\
\hline Phenobarbitone & $\begin{array}{l}\text { First line in neonatal seizures in the first } \\
\text { two years of life for partial seizures and } \\
\text { early infantile status epilepticus (SE) }\end{array}$ & $\begin{array}{l}\text { 3-6 (single night-time dose) } \\
20 \mathrm{mg} / \mathrm{kg} \text { (loading dose for } \\
\mathrm{SE} \text { ) }\end{array}$ & $\begin{array}{l}\text { Deleterious cognitive and } \\
\text { behavioral }\end{array}$ \\
\hline Phenytoin & $\begin{array}{l}\text { Should not be preffered as primary AED ir } \\
\text { newly diagnosed epilepsy }\end{array}$ & $\begin{array}{l}\text { Older children: 5-6 (once or } \\
\text { twice daily) } \\
\text { Infants: } 15-18 \text { (3-4 divided } \\
\text { dose) }\end{array}$ & $\begin{array}{l}\text { Poor seizure control } \\
\text { fluctuating drug level, gum } \\
\text { hyperplasia, hirsutism }\end{array}$ \\
\hline Valproate & $\begin{array}{l}\text { - } \quad \text { Broad spectrum efficacy } \\
\text { - Drug of Choice (DOC) for newly } \\
\text { diagnosed epilepsy }\end{array}$ & 10-40 (twice daily) & $\begin{array}{l}\text { Weight gain, hair loss, } \\
\text { aggravation of polycystic } \\
\text { ovarian disease (PCOD) }\end{array}$ \\
\hline Carbamazepine & $\begin{array}{l}\text { - First choice for newly diagnosed } \\
\text { partial epilepsies after the age of } 2 \\
\text { years. } \\
\text { - Focal, CTG and mixed types seizures } \\
\text { - } \quad \begin{array}{l}\text { Exacerbates myoclonic and absence } \\
\text { seizure }\end{array}\end{array}$ & 10-30 (twice daily) & $\begin{array}{l}\text { Ataxia, diplopia, rash, } \\
\text { school performance } \\
\text { worsening } \\
\text { Appearance of new seizures }\end{array}$ \\
\hline Ethosuximide & Absence epilepsy & 20-30 twice daily & $\begin{array}{l}\text { Abdominal discomfort, } \\
\text { hiccups, headaches, sedation }\end{array}$ \\
\hline Lamotrigine & $\begin{array}{l}\text { - } \quad \text { Monotherapy in focal seizures } \\
\text { Adjunctive therapy for seizures } \\
\text { associated with therapy refractory } \\
\text { Lennox Gastaut syndrome. }\end{array}$ & $0.2-0.5$ twice daily & $\begin{array}{l}\text { Skin rash, dizziness, ataxia, } \\
\text { SJS }\end{array}$ \\
\hline Gabapentin & $\begin{array}{l}\text { - Monotherapy in focal seizures } \\
\text { - } \quad \text { Adjunctive therapy for partial seizure }\end{array}$ & $\begin{array}{l}30-60 \text { ( } 3 \text { times daily) } \\
\text { (monotherapy: } \geq 12 \text { years) } \\
\text { (adjunctive: } \geq 3 \text { years) }\end{array}$ & $\begin{array}{l}\text { Somnolence, dizziness, } \\
\text { ataxia. } \\
\text { Fatigue blurred vision, } \\
\text { diplopia, rash, aggressive } \\
\text { behavior, weight gain. }\end{array}$ \\
\hline Oxcarbazepine & $\begin{array}{l}\text { Monotherapy or adjunctive for focal } \\
\text { seizures }\end{array}$ & 20-40 (twice daily) & $\begin{array}{l}\text { Sedation, headache, ataxia, } \\
\text { hyponatremia (rare) }\end{array}$ \\
\hline Topiramate & $\begin{array}{l}\text { Monotherapy with new diagnosed } \\
\text { epilepsy } \\
\text { Adjunctive therapy for focal seizures, } \\
\text { primary GTC seizures, Lennox } \\
\text { Gastaut syndrome }\end{array}$ & $\begin{array}{l}\text { Initial: } 0.5-1 \\
\text { Maintenance: } 3-9\end{array}$ & $\begin{array}{l}\text { Anorexia, weight loss, } \\
\text { begavior changes, } \\
\text { hyperthermia, renal stone, } \\
\text { ascidosis }\end{array}$ \\
\hline
\end{tabular}

\section{Mechanism of KD as anticonvulsant}

The anticonvulsant efficacy of the KD has been examined in various acute and chronic animal models of epilepsy over the years. In rodents, maximal seizure control develops 1-2 weeks after initiation of a KD. Similarly, in humans, clinical efficacy does not reach its zenith in many patients until after 2 weeks. ${ }^{8}$

\section{The role of ketone bodies}

There is some evidence that ketones other than BHB may possess anticonvulsant properties. When injected into animals, acetone and acetoacetate (ACA), prevent acutely provoked seizures. Recently, it has been suggested that ACA and/or its metabolic byproduct, acetone, may activate a novel class of potassium leak channels known as the two-pore domain or K2P channels. ${ }^{13} \mathrm{~K} 2 \mathrm{P}$ channels represent a diverse superfamily of channels that generally hyperpolarize cell membranes, and regulate membrane excitability both pre and postsynaptically. These channels can be modulated by changes in $\mathrm{pH}$, osmolality, temperature, mechanical pressure, and certain fatty acids. $^{8}$

$\beta$-hydroxybutyrate is the predominant blood ketone body and is oxidized to acetoacetate in the mitochondria before entering the TCA cycle. Rho and colleagues found that it was acetoacetate and acetone other than $\beta$ - 
hydroxybutyrate that can significantly decrease the epileptic seizures in the seizure-susceptible juvenile mouse model, indicating anticonvulsant effects of these ketone bodies. To investigate the effects of KD and anticonvulsant drug combination, Szot and his colleagues performed coadministration of valproate and ketogenic diet and examined its effect. In majority of the cases, it seemed safe to coadministrate valproate and ketogenic diet. Only in two cases, valproate made a negative influence on ketosis. Their research sheds new light on the combination strategy of $\mathrm{KD}$ and anticonvulsant drugs. ${ }^{14}$

Table 3: Types of ketogenic diet. ${ }^{9}$

\begin{tabular}{|c|c|c|c|c|}
\hline & \multicolumn{3}{|c|}{ Macrinutrient content ( $\%$ total daily calories) } & \multirow[t]{2}{*}{ Comments } \\
\hline & Fat & Protein & Carbohydrate & \\
\hline $\begin{array}{l}\text { Classic } \\
\text { ketogenic diet }\end{array}$ & LCT: $85-90$ & $6-8$ & $2-4$ & $\begin{array}{ll}\text { - } & 4: 3 \text { or } 3: 1 \text { (fat: nonfat) ratio } \\
\text { - } & \text { unpalatable= poor compliance } \\
\text { - } & \text { GI effects: constipation }\end{array}$ \\
\hline MCT diet & MCT: 71 & 10 & 19 & $\begin{array}{l}\text { - } \quad 3: 1 \text { (fat: nonfat) ratio } \\
\text { - } \quad \text { Easier to prepare } \\
\text { Greater flexibility with protein and } \\
\text { carbohydrate allowance } \\
\text { GI effects: cnausea, vomiting, diarrhea in } 50 \% \\
\text { patients }\end{array}$ \\
\hline $\begin{array}{l}\text { Modified MCT } \\
\text { diet }\end{array}$ & $\begin{array}{l}\text { LCT: } 40-5 \\
\text { MCT: } 30\end{array}$ & $10-2-$ & $5-10$ & $\begin{array}{ll}\text { - } & \text { Incorporates LCT and MCT } \\
\text { - } & \text { Fewer GI effects }\end{array}$ \\
\hline $\begin{array}{l}\text { Modified } \\
\text { Atkins diet }\end{array}$ & $60-70$ & $20-3-$ & 5 & $\begin{array}{ll}\text { - } & \text { No fasting or hospital stay } \\
\text { - } & \text { No calore restrictions } \\
\text { - } & \text { Less dietitian support }\end{array}$ \\
\hline $\begin{array}{l}\text { Low-glycemic- } \\
\text { index treatment } \\
\text { diet }\end{array}$ & $60-70$ & $20-3-$ & 10 & $\begin{array}{l}\text { - Only low glycemic index carbohydrate allowed } \\
\text { for } 10 \% \text { daily carbohydrates } \\
\text { - Details of how diet is prescribed are not widely } \\
\text { known }\end{array}$ \\
\hline
\end{tabular}

Table 4: Sample calculations of daily energy requirements for the $3: 1$ classic ketogenic diet for $18 \mathrm{~kg}$ patient. ${ }^{9}$

\section{Daily energy requirements}

Daily caloric requirement

- Total body weight x $68 \mathrm{cal} / \mathrm{kg} /$ day

- $18 \mathrm{~kg} \mathrm{x} 68 \mathrm{cal}=1224 \mathrm{cal} /$ day

Daily number of dietary units

- For 3:1 (fat: prtoein/ carbohydrates)

- $3 \mathrm{~g}$ fat/ unit $\times 9 \mathrm{cal} / \mathrm{g}$ fat $=27$ calories

- $1 \mathrm{~g}$ protein or $\mathrm{CHO} /$ unit $\times 4 \mathrm{cal} / \mathrm{g}$ protein or carbohydrates $=4$ calories

- $27+4=31$ calories/ unit

- daily caloric requrement: calories/unit= dietary units/ day

- $\quad$ a. $1224: 31=39$ units/ day

Daily fat content

- Dietary units/day $\times \mathrm{g}$ fat/ unit= g fat/ day

- 39 units/day x $3 \mathrm{~g}$ fat/unit= $117 \mathrm{~g}$ fat/ day

Daily protein and CHO content (combined)

- Dietary units/ day x g protein or $\mathrm{CHO} / \mathrm{unit}=\mathrm{g}$ protein or $\mathrm{CHO} /$ day

- 39 units/ day x $1 \mathrm{~g}$ protein or $\mathrm{CHO} /$ unit= $39 \mathrm{~g}$ protein and $\mathrm{CHO} /$ day

Daily protein content $=1 \mathrm{~g} / \mathrm{kg} /$ day

- $1 \mathrm{~g} / \mathrm{kg} /$ day x $18 \mathrm{~kg}=18 \mathrm{~g} /$ day

Daily carbohydrate content

- Combined protein and cho content- daily protein content $=$ daily carbohydrate content

- $39 \mathrm{~g}$ protein and cho/day- $18 \mathrm{~g}$ protein/day= $21 \mathrm{~g} \mathrm{CHO} /$ day

Divide allotment into 3 meals

- Fat $=117: 3=39 \mathrm{~g} /$ meal

- Protein 18: $3=6 \mathrm{~g} / \mathrm{meal}$

- $\quad$ cho $21: 3=7 \mathrm{~g} /$ meal 


\section{The effect of KD on neuron metabolism}

The brain metabolizes ketone bodies for energy when glucose levels are rapidly decreased during KD. It has been established that the efficacy of the KD for managing epilepsy is best when the diet is administered following a fast or when total calories are restricted. Furthermore, the seizure protective effects of KD are found to rely on the maintenance of low blood glucose levels which force the brain to burn ketones for energy. Ketone metabolism gradually reduces neuronal excitability, thereby producing effects on neurotransmitter levels and neuron membrane potential. ${ }^{15}$

\section{The effects of KD on neurotransmitter function}

GABA signaling is the most well studied target of investigation since mouse models of epilepsy induced by GABA antagonists exhibited a remarkable response to KD treatment. Moreover, in rat synaptosomes GABA synthesis was greatly increased and maintained at a high level by ketone bodies, which may contribute to the beneficial effect of $\mathrm{KD}$ in the treatment of epilepsy. Many clinical studies showed increased GABA levels in the cerebrospinal fluid of patients on a KD, further supporting that GABA might be regulated by ketone bodies. $^{15}$

\section{The effect of KD on neuronal membrane}

Another potential mechanism underlying the effects of ketone bodies on epileptic seizures is their effects on neuronal membrane transporters. Ketone bodies may alter the behavior of vesicular glutamate transporters (VGLUTs) that are responsible for filling presynaptic vesicles with glutamate in a $\mathrm{Cl}$-dependent manner. Juge and colleagues demonstrated that $\mathrm{Cl}$ - is an allosteric activator of VGLUTs that is competitively inhibited by ketone bodies (acetoacetate) more strongly than $\beta$ hydroxybutyrate.

Abnormal gap junctional communication is an underlying mechanism involved in the generation and maintenance of seizures. Consequently, the effects of gap junction blockers were determined in seizure models. As a result, these gap junction blockers can reduce both amplitude and frequency of the epileptiform activity, and modify the behavioral parameters related to seizures in vivo assay. However, no clinical evidence supported the correlation between KD treatment and the gap junctional communication. ${ }^{15}$

\section{Role of fatty acid on $K D$}

PUFAs are becoming an increasingly popular focus of KD research. After KD treatment, specific PUFAs (i.e., DHA) were found to be elevated in both serum and brain of patients and animals. One report documented that the rise (or drop) in total fatty acids during $\mathrm{KD}$ treatment closely paralleled clinical improvement of seizure control. PUFAs could ultimately block seizure activity in a number of ways (Figure 4). First, PUFAs may inhibit directly ion channel activity. Omega-3 ( $\omega-3)$ PUFAs have been shown to inhibit both voltagegated $\mathrm{Na}+$ and $\mathrm{Ca} 2+$ channels, increase the resistance to bursting induced by bicuculline, zero $\mathrm{Mg} 2+$, pentylenetetrazole or glutamate, and prolong the recovery time from inactivation in hippocampal neurons. Second, in conjunction with ketone bodies, PUFAs may activate a lipid-sensitive class of K2P potassium channels. And, third, PUFAs may enhance the activity of the $\mathrm{Na}+/ \mathrm{K}+-\mathrm{ATPase}$ (sodium pump). Elevated $\omega-3$ and diminished $\omega-6$ PUFAs levels in plasma membranes significantly increased sodium pump function. These findings indicate that elevations levels of PUFAs after KD treatment might act directly to limit neuronal excitability and dampen seizure activity. ${ }^{8}$ The ketogenic diet pathways can be seen in Figure 4 .

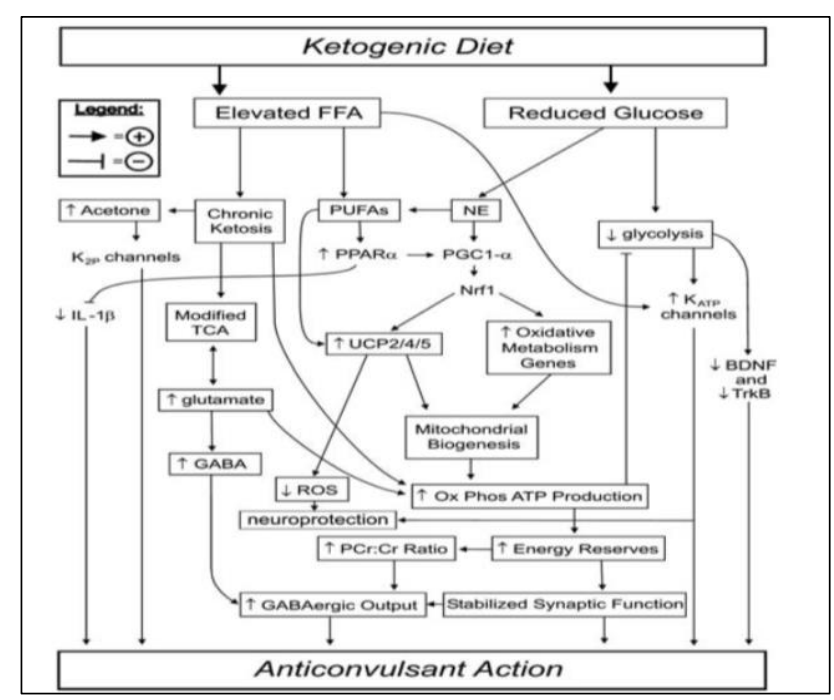

Figure 4: Ketogenic diet pathways. ${ }^{8}$

\section{The role of glucose restriction}

Others have hypothesized that glucose restriction during KD treatment activates ATP-sensitive potassium (KATP) channels. Interestingly, KATP channels are ligand gated receptors broadly expressed throughout the central nervous system, in both neurons and glia. These channels act as metabolic sensors, linking cellular membrane excitability to fluctuating levels of ADP and ATP. Activation of this receptor by reduced ATP/ADP ratios opens the channel and leads to membrane hyperpolarization. When glucose is limited, KATP channels might open to hyperpolarize the cell as the intracellular ATP concentrations fall. Conversely, when glucose is present and ATP concentrations rise, KATP channels close. As such, KATP channels may provide a measure of protection against a variety of metabolic stressors such as hypoxia, ischemia, and hypoglycemia, and are believed to regulate seizure threshold. Genetically engineered mice that overexpress the sulfonylurea (SUR) 
subunit of KATP channels were significantly more resistant to seizures induced by kainite and showed no marked cell loss in hippocampus. Studies of KATP channel knockout mice suggested that these channels help determine seizure threshold. Following hypoxic challenge, knock out mice exhibited myoclonic-tonic seizure activity, and, ultimately, death compared to controls who all recovered without sequelae. several findings are consistent with the no- tion that KATP channels are selectively activated during administration of a low-glucose, high-fat KD. ${ }^{8}$

\section{Adverse effects}

The most common adverse effect of the KD is constipation. The regular inclusion of fibrous vegetables, carbohydrate- free stool softeners, mild laxatives, and sufficient fluids are helpful in maintaining bowel regularity. ${ }^{1}$ Sampaio et al, report that in their study, the most frequently reported adverse effects were hunger, constipation, and hypoactivity. ${ }^{10}$

\section{DISCUSSION}

There were many randomized controlled trials on ketogenic diet for children with refractory epilepsy. One of them are Neal et al, who found that there is no significant difference in the efficacy of the treatment between symptomatic generalized or symptomatic focal syndromes. She reports the most frequent side effects were constipation, vomiting, lack of energy and hunger. Weijenberg et al, studied the ketogenic diet in liquid form and their study concludes that ketogenic diet with a liquid formulation is feasible and can be safely introduced in an outpatient setting. As from Lambrecth et al, their study result in the effective therapy in children with refractory epilepsy is with ketogenic diet rather than standard therapy and the side effects were gastrointestinal symptoms, it is the same as other studies implied. From Sampaio et al, it was said in the study that KD is effective in reducing the frequency of seizures and improving cognition and the quality of life of patients. ${ }^{10}$

\section{CONCLUSION}

In conclusion, this review article summarized many important aspects of pediatric epilepsy and the role of ketogenic diet in treating epilepsy. The antiepileptic efficacy of KD in epilepsy has been found to increase the number of experimental evidences and raise a promising therapeutic strategy against epilepsy. This review article shown that the diet has efficacy and should be included in the management of children who have drug-resistant epilepsy. However, the diet is not without possible sideeffects, which should be considered alongside the riskbenefit of other treatments when planning the management of such children.
Funding: No funding sources

Conflict of interest: None declared

Ethical approval: Not required

\section{REFERENCES}

1. Kania BAZ, Spellman E. An overview of the ketogenic diet for pediatric epilepsy. Nutrition in Clin Prac. 2008;23(6):589-95.

2. Liu G, Slater N, Perkins A. Epilepsy: treatment options. Am Acad Fam Physician. 2017;96(2):87,90-5.

3. Saad K. Childhood epilepsy: an update on diagnosis and management. Am J Neurosci. 2014;5(2):36-9.

4. Jan MM. Clinical review of pediatric epilepsy. Saudi Arabia: Neurosci. 2005;10(4):255-64.

5. Flynn S, Babi MA. Anticonvulsants. Pharmacol Therap Dentistry. 2017;12(1):176-92.

6. Kumar S, Singh G. Pathophysiology of epilepsy: an updated review. Int J Med Heal Res. 2016;2:32-6.

7. Expert committee on pediatric epilepsy. Guidelines for diagnosis and management of childhood epilepsy. Ind Acad Pediatrics. 2007(1);46:685-93.

8. Bough KJ, Rho JM. Anticonvulsant mechanisms of the ketogenic diet. Epilepsia. 2007;48(1):43-58.

9. Runyon AM, So TY. The use of ketogenic diet in pediatric patients with epilepsy. ISRN Ped. 2012;1:1-10.

10. Sampaio LPDB, Takakura C, Manreza MLG. The use of a formula-based ketogenic diet in children with refractory epilepsy. Brasil: Sci Elo. 2017;75(4):234-37.

11. Neal EG, Chaffe H, Schwartz RH. The ketogenic diet for the treatment of childhood epilepsy: a randomised controlled trial. Lancet Neurol. 2008;7(1):500-06.

12. Lambrechts DAJE, Kinderen RJA, Vles JSH, Aja DL, Aldenkamp AP, Majoie HJM. A randomized controlled trial of the ketogenic diet in refractory childhood epilepsy. John Wiley Sons Ltd. 2016; $1: 1-9$.

13. Vamecq J, Vallee L, Lesage F, Gressens P, Stables JP. Antiepileptic popular ketogenic diet: emerging twists in an ancient story. Elsevier Progress Neurobiol. 2005;75:1-28.

14. Spilioti M, Pavlou E, Gogou M, Katsanika I, Alataki PE, Grafakou O, et al. Valproate effect on ketosis in children under ketogenic diet. Euro J Paediatr Neurol. 2016;20(4):555-9.

15. Zhang Y, Xu J, Zhang K, Yang W, Li B. The anticonvulsant effects of ketogenic diet on epileptic seizures and potential mechanisms. Current Neuropharmacol. 2018;16(1):66-70.

Cite this article as: Kurnia B. Ketogenic diet: a promising alternative nonpharmacology treatment for pediatric epilepsy. Int J Contemp Pediatr 2019;6:1773-81. 